\title{
Peran Iklim Sekolah terhadap Perundungan
}

\author{
Sri W Rahmawati ${ }^{1}$ \\ Fakultas Psikologi Universitas Tama Jagakarsa
}

\begin{abstract}
Bullying is like an iceberg. Although more than $79 \%$ of students reported to have experienced bullying, but only $21 \%$ of cases of bullying are listed. Although a number of interventions have been done to prevent bullying, however there is not a significant result. Bullying happens in schools can not be separated from school climate. There are three dimensions of school climate: teacher caring and respect, school goal and norms, and peer relation. Aim of this study was examined the role of school climate toward bullying. School climate scale and scale of bullying were used as measuring tools to see the role of school climate on prevent bullying. Seven hundred and twenty-three senior high school students from five regions in Jakarta, were sampled in this study using cluster random sampling technique. I found the components of school climate have significant negative correlations to bullying. These findings suggest that efforts to address bullying should involve the school climate improvement process.
\end{abstract}

Keyword: bullying, senior high school student, school climate

Abstrak. Perundungan merupakan fenomena gunung es. Meskipun lebih dari 79\% siswa dilaporkan pernah mengalami perundungan, namun hanya $21 \%$ kasus perundungan yang terangkat ke permukaan. Sejumlah intervensi telah dilakukan untuk mencegah terjadinya perundungan, namun belum memberikan hasil yang signifikan. Perundungan yang terjadi di sekolah tidak bisa dilepaskan dari iklim sekolah. Terdapat tiga hal utama dalam pencegahan perundungan, yaitu: dukungan/perhatian guru, pembentukan nilai dan norma sekolah yang sehat, serta relasi antar teman sebaya. Penelitian ini bertujuan untuk mengungkap peran iklim sekolah terhadap perundungan. Riset terhadap 723 siswa yang berasal dari lima wilayah provinsi DKI Jakarta, dilakukan dengan menggunakan teknik sampling kluster acak. Skala iklim sekolah dan skala perundungan digunakan sebagai alat ukur dalam penelitian ini. Hasil riset menunjukkan bahwa komponenkomponen iklim sekolah memiliki korelasi signifikan dengan arah negatif terhadap perundungan. Hasil penelitian ini menyarankan pentingnya peningkatan iklim sekolah dalam penanganan perundungan.

Kata kunci: iklim sekolah, perundungan, siswa SMA

Menjelang pertengahan tahun 2016 lalu, video perundungan siswa SMAN XYZ (nama disamarkan) di Jakarta beredar di youtube. Pada tayangan tersebut, para siswa yang merupakan adik kelas, disiram air dari teh botol dan abu rokok. Mereka

\footnotetext{
${ }^{1}$ Korespondensi mengenai isi artikel ini dapat dilakukan melalui: swrahma@yahoo.com
}

juga dimaki-maki oleh kakak kelasnya dan dipaksa menggunakan pakaian dalam di luar pakaiannya.

DKI Jakarta merupakan kota metropolitan yang menjadi etalase. Perilaku siswa di SMA DKI sering kali menjadi cermin bagi siswa lain di segenap penjuru negara ini, dan dengan cepat dijadikan 
model untuk ditiru. Pemerintah daerah DKI Jakarta tidak kurang telah memberikan peringatan sangat keras: bila perundungan terjadi, maka pelaku akan dikeluarkan dari sekolah tanpa dispensasi, dan kepala sekolah akan dicopot dari jabatannya. " .... Dinas Pendidikan DKI Jakarta tidak akan meluluskan pelajar pelaku perundungan dan tindak kekerasan lain. Selain siswa, guru dan kepala sekolah juga tak luput dari ancaman pemecatan jika dianggap tak berhasil menegakkan ketertiban di antara para pelajar...", demikian pernyataan Gubernur Basuki Tjahaya Purnama menanggapi kejadian perundungan (news.Okezone .com/read/2016/05/09/338/1383574/ahokancam-pecat-guru-yang-membiarkanperundungan-di-sekolah).

Meski sudah sedemikian rupa sanksi disiapkan, namun kasus-kasus perundungan sebagaimana yang dirilis dalam video di atas, masih saja ditemukan. Tindak agresi di sekolah-sekolah di Jakarta, dan juga di beberapa kota besar lainnya di Indonesia, sesungguhnya telah berlangsung lama, bahkan sebagiannya sudah menjadi tradisi. Saat tahun ajaran baru, program MOS (masa orientasi siswa) sering menjadi ajang perundungan siswa senior kepada adik kelas juniornya. Menurut Djuwita, peneliti perundungan pada sekolah di beberapa kota besar di Indonesia, perundungan antara seniorjunior; ataupun antar teman sebaya yang berada pada tingkat kelas yang sama, pada sekolah-sekolah tertentu seolah menjadi tradisi yang dipelihara sebagai ciri khusus sekolah (Abidin \& Mila, 2013).

Sebagai sebuah lembaga pendidikan, tindak agresi di sekolah merupakan suatu ironi (Ttofi, Farrington, Losel, \& Loeber, 2011), karena sekolah seharusnya menjadi tempat terhormat di mana nilai-nilai positif seperti sopan santun, respek antar teman dan warga sekolah lainnya, maupun keterampilan sosial lainnya ditanamkan (Hoffman, 2010). Douglass (2009) melaporkan bahwa frekuensi terjadinya perundungan dan bentuk agresi lainnya merupakan problem terbesar yang dihadapi sekolah. Tindak agresi yang terjadi di sekolah pada lingkungan perkotaan, ditengarai juga lebih tinggi bila dibandingkan tempat lainnya (McCaskill, 2013; Crapanzano, 2010).

Laporan dari Yayasan Semai Jiwa Amini (Sejiwa), sebuah lembaga nirlaba yang mengkhususkan perhatiannya pada perilaku perundungan di sekolah (http:// sejiwa.org/profile/) melakukan survei terhadap 1500 pelajar SMP dan SMA di Jakarta, Yogyakarta, dan Surabaya. Menurut survei tersebut, $67 \%$ responden menyatakan, bahwa perundungan pernah terjadi di sekolah mereka. Pelakunya adalah teman, kakak kelas, adik kelas, guru, kepala sekolah, hingga preman yang berada di sekitar sekolah (Rahmawati, 2017). Adair (1999) menyebut kekhasan fenomena di atas sebagai "the bullying iceberg". Adair (1999) melaporkan dalam penelitiannya, bahwa perundungan yang dilaporkan terjadi hanya sekitar 21\%, sementara $79 \%$ siswa yang pernah menjadi korban perundungan tidak melaporkan kejadian tersebut kepada guru ataupun orang tua mereka. Sebanyak $50 \%$ yang mengalami perundungan dinyatakan tidak dapat menghentikan ataupun memiliki strategi tertentu untuk menghentikannya. Selain itu, ada kecenderungan bila perilaku perundungan akan tampil meningkat bila diperkuat oleh kelompok (peer group), dan dilakukan terhadap orang lain di luar kelompoknya (Pozzoli \& Gini, 2010).

Kasus-kasus perundungan menggerakkan sekolah di berbagai negara untuk menegakkan semboyan NCLB (No Child Left Behind), dengan mulai berbenah dan 
melakukan pendataan terhadap kejadian perundungan serta upaya intervensi untuk mengatasinya. Namun meskipun sudah dibuat intervensi sedemikian rupa, hasilnya masih jauh dari harapan. 17 dari 28 (sekitar 60\%) sekolah yang melakukan program intervensi dalam penelitian Kenneth, Barbara, Scott, dan Duane (2013) ternyata hanya memberikan hasil yang kurang signifikan. Intervensi dalam bentuk pelatihan untuk guru, penyadaran terhadap siswa untuk menghindari perila$\mathrm{ku}$ perundungan, memberikan konsultasi kepada korban perundungan agar mau melaporkan kejadian, ternyata kurang memberikan dampak positif. Hasil penelitian ini memberikan rekomendasi, bahwa akan lebih bermakna bila mengatasi perilaku perundungan dengan cara menciptakan lingkungan berupa konteks sekolah yang memiliki suasana yang sehat. Dengan kata lain, untuk mencegah meluasnya perundungan di sekolah, perlu diciptakan iklim sekolah yang sehat (Kogan, 2011; Paramo, 2012).

Sekolah yang sehat memiliki misi dan tujuan yang difahami oleh setiap orang yang terlibat di dalamnya, baik guru maupun siswa. Di sisi lain, salah satu ciri sekolah yang tidak sehat, bila misi dan tujuan sekolah ditentukan oleh orang tua atau masyarakat (Waasdorp, Bradshaw, \& Duong, 2011). Iklim sekolah merupakan persepsi sosial terhadap lingkungan yang terdapat di sekolah pada dimensi-dimensi sebagai berikut: pertama, iklim sekolah merupakan faktor kontekstual yang memengaruhi pembelajaran dan dan perkembangan siswa di sekolah; kedua, iklim sekolah relatif stabil dari waktu ke waktu dan ketiga, iklim sekolah dapat dirasakan bermakna bagi banyak warga yang terlibat di dalamnya. Pengertian iklim sekolah ini lebih merujuk pada persepsi terhadap lingkungan sosial yang dimiliki guru, siswa maupun staf akade- mik lainnya di sekolah, dibandingkan dengan keadaan obyektifnya (Sutherland, 2010). Iklim sekolah merupakan "jantung" dan "ruh" sekolah, yang membuat seorang guru ataupun siswa memiliki perasaan tertentu pada sekolahnya, seperti perasaan senang atau justru sebaliknya (Ryan, 2009). Sekolah yang memiliki iklim yang positif akan mengundang guru dan siswa merasa nyaman berada di dalamnya dan mendorong mereka untuk menampilkan kemampuan terbaiknya (Jimmerson dkk, 2009). Siswa akan termotivasi untuk menunjukkan pencapaian akademis, dan di sisi yang lain tidak berminat pada aktivitas agresif.

Terdapat delapan komponen iklim sekolah untuk mengurangi perilaku perundungan, yaitu: unggul dalam pembelajaran, nilai/norma sekolah, kesadaran terhadap kelebihan/kekurangan sekolah, kebijakan dan keterbukaan sekolah, perhatian dan penghargaan, harapan yang positif, dukungan guru serta karakteristik lingkungan fisik sekolah. Dari beberapa komponen tersebut, maka penelitian ini akan membatasi pada tiga komponen penting utama dalam iklim sekolah (Socoski, 2006; Summers 2008) yang berhubungan dengan pencegahan terjadinya perundungan, yaitu: (a) teacher caring and respect/perhatian dan penghargaan guru, (b) school goals and norms /tujuan dan norma sekolah, serta (c) peer relations/relasi teman sebaya. Iklim sekolah yang sehat akan menjadi langkah preventif dalam pencegahan terbentuknya korban perundungan di sekolah. Dengan iklim sekolah yang baik, setiap warga sekolah memiliki rasa tanggung jawab satu sama lain, serta keterikatan emosional. Hal tersebut membuat aturan-aturan yang menjadi panduan, dijalankan secara konsisten untuk kebahagiaan semua warga sekolah. 
Berdasarkan penjelasan di atas maka tujuan dari penelitian ini adalah menguji kontribusi iklim sekolah terhadap perilaku perundungan. Hipotesis yang diajukan peneliti adalah: (a) iklim sekolah memiliki korelasi negatif yang signifikan terhadap perundungan; dan (b) iklim sekolah memiliki kontribusi dalam mencegah perundungan di sekolah.

\section{Metode}

Populasi dari penelitian ini adalah siswa SMA di wilayah Jakarta. Penarikan sampel dilakukan sesuai dengan karakteristik populasi, dengan menggunakan teknik cluster random sampling. Satu kecamatan dari lima wilayah ibu kota, yaitu Jakarta Selatan, Jakarta Timur, Jakarta Barat, Jakarta Utara dan Jakarta Pusat, masing-masing dipilih secara acak. Setelah itu, dipilih pula secara acak satu SMA pada kecamatan yang dimaksud. Partisipan dalam penelitian ini sejumlah 723 siswa SMA dengan sebaran sebagai berikut (Tabel 1).

Setelah memperoleh izin dari Dinas Pendidikan DKI Jakarta serta pimpinan sekolah terkait, pengambilan data dilakukan selama kurang lebih 1 bulan pada Januari 2016. Siswa yang dijadikan responden adalah siswa kelas XI SMA dengan pertimbangan mereka sudah mengenal lebih dekat teman-teman seko- lahnya, dibandingkan siswa kelas X SMA. Selain itu, mereka juga belum disibukkan dengan persiapan Ujian Nasional sebagaimana siswa kelas XII SMA.

Alat ukur iklim sekolah dikembangkan dari skala School Social Competence Development (Orpinas dan Horne, 2006) serta skala Communal School Organization dari Gottferson dkk (Gottfredson, Gottfredson, Payne, \& Gottfredson, 2005). Dari kedua alat ukur ini, peneliti melakukan analisis teoritis dan menghasilkan sintesa alat ukur Skala Iklim Sekolah yang terdiri dari tiga dimensi, yang masingmasing dimensi berisikan 10 butir pernyataan: (a) perhatian dan penghargaan guru; (b) tujuan dan norma sekolah; serta (c) relasi antar teman sebaya. Skala Iklim Sekolah ini terdiri dari enam pilihan jawaban bertipe Likert, masing-masing dengan pilihan "sangat tidak setuju-tidak setuju-agak tidak setuju-agak setujusetuju-sangat setuju“. Contoh pernyataan untuk dimensi perhatian dan penghargaan guru adalah: "Guru di sekolah ini menghargai prestasi siswanya"; untuk dimensi tujuan dan norma sekolah adalah: "Aturan di sekolah ini membuat siswa merasa aman"; dan untuk dimensi relasi teman sebaya, contoh pernyataannya: "Siswa di sekolah ini mengabaikan satu sama lain". Sementara kuesioner yang digunakan untuk mengukur perundungan diadaptasi dari skala "My Life in School Chekclist" (Arora, 1994).

Tabel 1

Data partisipan penelitian

\begin{tabular}{cllcc}
\hline No & Wilayah & \multicolumn{1}{c}{ Kecamatan } & Nama Sekolah* & Jumlah Partisipan \\
\hline 1 & Jakarta Utara & Kelapa Gading & SMAN A & 131 \\
2 & Jakarta Barat & Tambora & SMAN B & 164 \\
3 & Jakarta Pusat & Sawah Besar & SMAN C & 68 \\
4 & Jakarta Timur & Pasar Rebo & SMAN D & 196 \\
5 & Jakarta Selatan & Cilandak & SMAN E & 164 \\
\hline & & & Jumlah total & 723 \\
\hline
\end{tabular}

*Nama sekolah disamarkan 
Skala terdiri dari 12 pernyataan. Contoh pernyataannya adalah: "Dalam enam bulan terakhir ini, saya mendorong teman saya dengan kasar". Responden mengisi dengan cara memilih alternatif jawaban dalam enam pilihan, yaitu: tidak pernah-hampir tidak pernah-jarang-kadang-sering-selalu.

Kedua alat ukur yang digunakan dalam penelitian ini telah melalui proses pengujian validitas maupun reliabilitas. Validitas yang digunakan berupa validitas tampang serta validitas isi. Setelah proses uji validitas selesai, selanjutnya dilakukan uji reliabilitas yang dilakukan terhadap pernyataan yang sudah valid. Pengujian dilakukan dengan mengukur konsistensi internal alpha cronbach yang diolah dengan menggunakan program SPSS 23. Alat ukur terdiri dari pernyataan yang mendukung/ berasosiasi positif dengan konstruk alat ukur; dan pernyataan yang berlawanan/ berasosiasi negatif dengan konstruk alat ukur. Dalam pengolahannya kemudian, butir pernyataan yang berlawanan tersebut dibalik hasil penilaiannya terlebih dahulu sebelum dilakukan tabulasi data. Hasil uji reliabilitas menujukkan alat ukur memiliki reliabilitas yang tergolong baik dan baik sekali, sebagaimana tersaji dalam tabel 2.
Pengolahan keseluruhan data penelitian ini menggunakan teknik statistik berupa uji perbedaan nilai rata-rata dan uji regresi. Data diolah menggunakan program SPSS versi 23.

\section{Hasil}

Deskripsi dari hasil penelitian terlihat pada tabel di bawah ini, meliputi gambaran iklim sekolah pada masingmasing SMA, gambaran perundungan pada masing-masing SMA, serta uji perbedaan perundungan dan iklim sekolah pada masing-masing SMA di wilayah DKI Jakarta.

Berdasarkan gambar 1 terlihat, bahwa secara umum siswa SMAN pada lima sekolah pada lima wilayah ibu kota Jakarta mempersepsi iklim sekolah mereka tergolong pada kategori sedang, hanya siswa di SMAN di Jakarta Selatan saja yang menilai iklim sekolah mereka umumnya tinggi. Hal tersebut menunjukkan bahwa siswa SMAN di wilayah ibu kota memiliki penilaian bahwa iklim sekolah baik pada aspek dukungan dan perhatian guru, aspek kejelasan aturan dan norma sekolah, maupun aspek relasi antar sebaya, pada umumnya berada pada kategori sedang.

Tabel 2.

Hasil uji alat ukur penelitian

\begin{tabular}{llccccc}
\hline No & Alat Ukur & $\begin{array}{c}\text { N of } \\
\text { items }\end{array}$ & Rerata & SD & Range $\begin{array}{c}\text { Alpha } \\
\text { Cronbach }\end{array}$ \\
\hline $\mathbf{1}$ & IS1_Perhatian \& Penghargaan Guru & 10 & 42,3721 & 7,88920 & $12-60$ &, 859 \\
\hline $\mathbf{2}$ & IS2_Tujuan \& Norma Sekolah & 10 & 36,1466 & 6,83324 & $16-56$ &, 711 \\
\hline $\mathbf{3}$ & IS3_Relasi Teman Sebaya & 10 & 38,5740 & 8,14267 & $10-60$ &, 881 \\
\hline $\mathbf{4}$ & Skala Iklim Sekolah & 30 & 117,0927 & 19,14447 & $57-168$ &, 908 \\
\hline $\mathbf{5}$ & Skala Perundungan & 12 & 24,7455 & 9,12389 & $12-72$ &, 861 \\
\hline
\end{tabular}

Keterangan: IS = Iklim Sekolah 


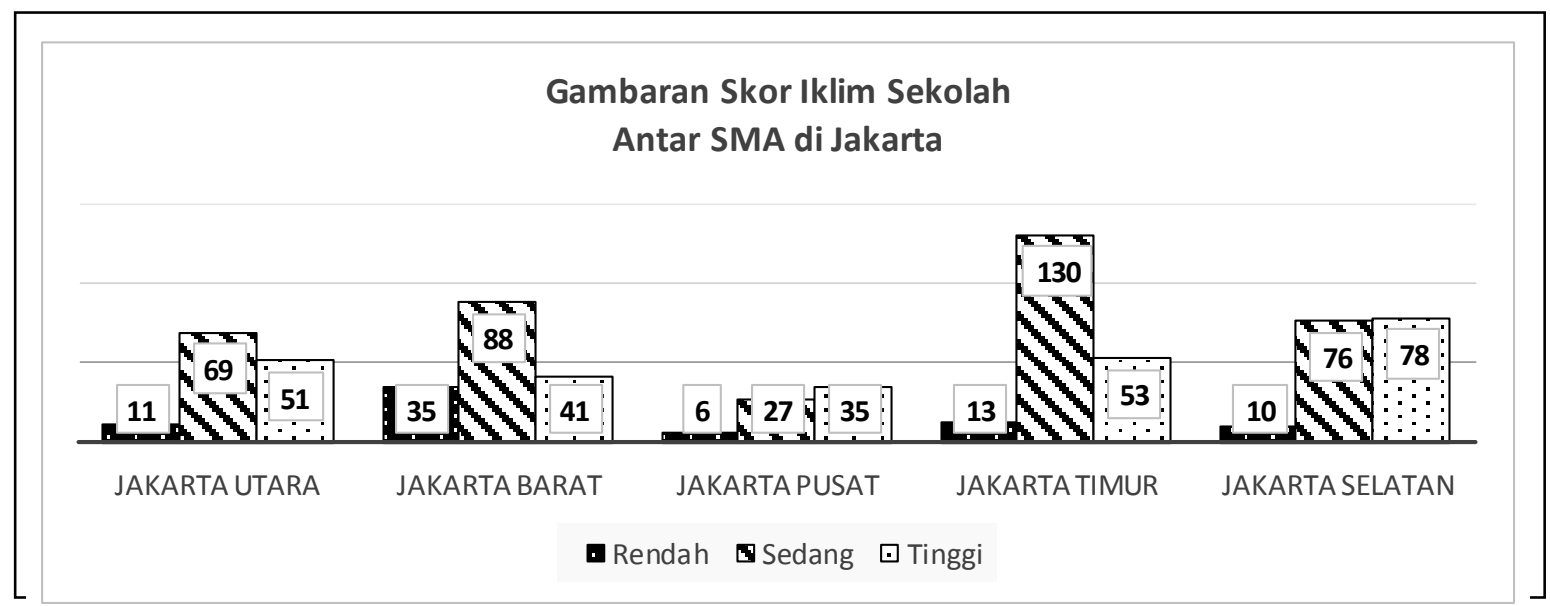

Gambar 1. Iklim Sekolah

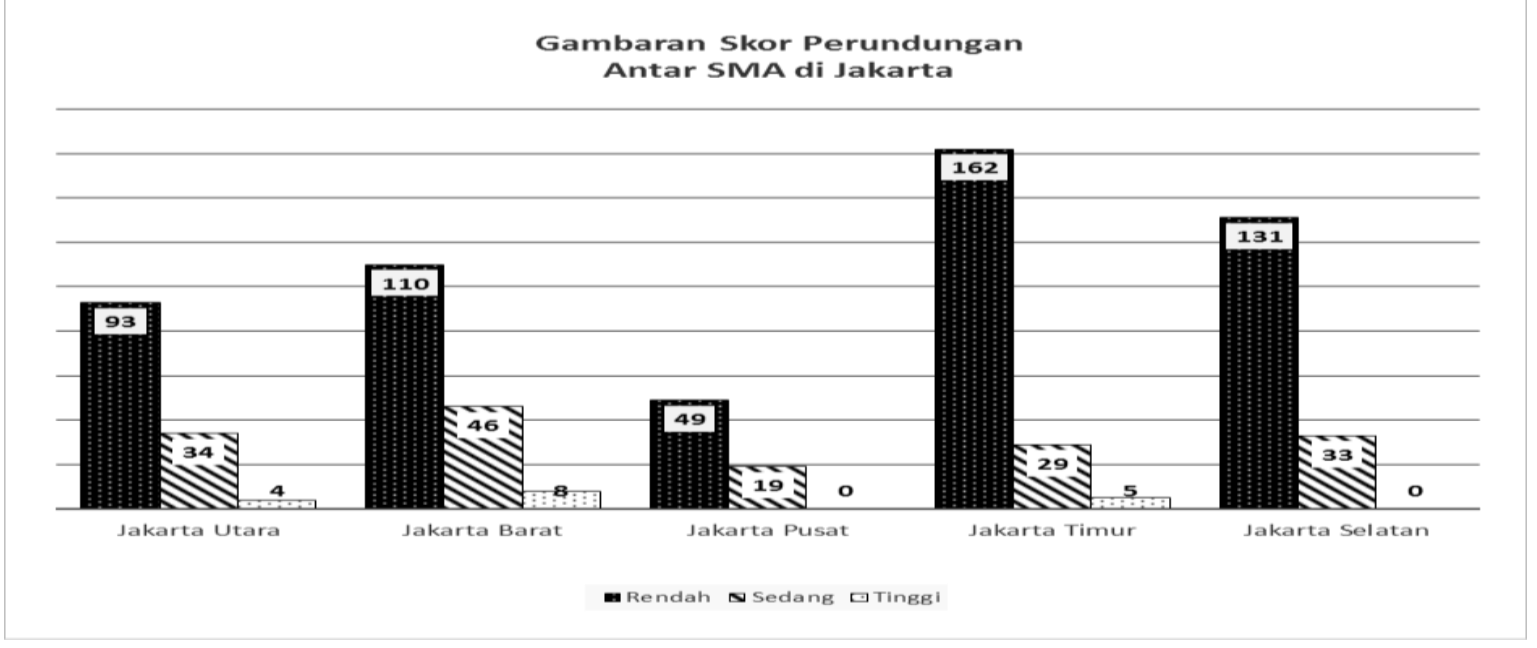

Gambar 2. Perundungan

Gambar 2. Perundungan menjelaskan sebaran skor perundungan di antara berbagai SMAN di Jakarta. Sebagaimana grafik batang yang terlihat pada gambar 2., pada umumnya siswa di SMAN Jakarta yang berasal dari lima wilayah ibu kota menilai perundungan yang terjadi di sekolah mereka tergolong rendah. Penilaian ini tampak merata, terlihat baik pada SMAN di Jakarta Utara, Jakarta Pusat, Jakarta Timur dan Jakarta Selatan. Bahkan pada SMAN Jakarta Selatan terlihat tidak ada satu siswa pun yang mengkategorikan perundungan di sekolah mereka tergolong pada kategori tinggi.

Tabel 3. menjelaskan hasil deskriptif untuk melihat skor rata-rata maupun standar deviasi tiap sekolah. Setelah itu, peneliti akan memaparkan hasil uji perbedaan antar sekolah pada variabel iklim sekolah dan perundungan. Perbedaan-perbedaan tersebut dapat dilihat pada penjelasan Tabel 3 di bawah.

Berdasarkan pengujian, terlihat adanya perbedaan yang signifikan pada skor iklim sekolah di setiap SMA, di mana $F(4,718)=13,66, p=, 000$. Hasil uji post hoc menggunakan Tukey HSD menunjukkan bahwa skor iklim sekolah di SMAN B Jakarta Barat $(M=104,96, S D=30,97)$ lebih rendah secara signifikan dibandingkan dengan skor iklim sekolah di SMAN A Jakarta Utara $(p=, 000)$, di SMAN C Jakarta Pusat $(p=, 000)$, di SMAN D 
Tabel 3

Hasil perhitungan deskriptif iklim sekolah pada setiap SMA

\begin{tabular}{clcccc}
\hline No & Wilayah & Nama Sekolah & Jumlah & Mean (M) & SD \\
\hline 1 & Jakarta Utara & SMAN A & 131 & 120,60 & 28,16 \\
2 & Jakarta Barat & SMAN B & 164 & 104,96 & 30,97 \\
3 & Jakarta Pusat & SMAN C & 68 & 126,24 & 29,70 \\
4 & Jakarta Timur & SMAN D & 196 & 114,60 & 25,64 \\
5 & Jakarta Selatan & SMAN E & 164 & 125,60 & 29,12 \\
\hline
\end{tabular}

Jakarta Timur $(p=, 013)$, dan SMAN E Jakarta Selatan $(p=, 000)$. Selain itu, hasil uji post hoc juga memperlihatkan bahwa skor iklim sekolah di SMAN D Jakarta Timur $(M=114,6, S D=25,64)$ lebih rendah secara signifikan dari skor iklim sekolah di SMAN E Jakarta Selatan $(p=, 003)$ dan SMA Jakarta Pusat $(p=, 032)$. Sementara itu, tidak terlihat adanya perbedaan skor iklim sekolah yang signifikan di antara SMAN yang terletak di area Jakarta Selatan, Jakarta Pusat, dan Jakarta Utara.

Selanjutnya, pengujian terhadap skor perundungan pada setiap sekolah tampak pada tabel 4 .

Berdasarkan Tabel 4 di atas, SMAN C di area Jakarta Pusat memiliki skor perundungan yang lebih tinggi dibandingkan keempat SMA lainnya, sedangkan SMAN E di Jakarta Selatan memiliki skor perundungan terendah dibandingkan keempat SMA lainnya. Untuk melihat seberapa jauh perbedaan tersebut signifikan maka peneliti menggunakan Welch's F test, dikarenakan asumsi homogenity of variance yang terlihat berdasarkan Levene's F test tidak terpenuhi $(p=, 000)$. Hasil Welch's F test menunjukkan adanya perbedaan yang signifikan pada skor perundungan pelaku di setiap SMA [Welch's $F(4,290,84)=3,493, p=$,008]. Berdasarkan uji post-hoc menggunakan Tukey HSD, terlihat bahwa skor perundungan pelaku di SMAN E di Jakarta Selatan $(M=23,02, S D=8,86)$ lebih rendah secara signifikan dibandingkan SMAN B di Jakarta Barat $(M=26,68, S D=13,73)$, di mana $p=$,024. Selain perbedaan tersebut, tidak ada skor perundungan pelaku yang terbukti signifikan di antara SMA-SMA lainnya.

Hipotesis utama penelitian ini adalah menguji korelasi antara iklim sekolah terhadap perundungan. Dari ketika komponen iklim sekolah, yaitu: perhatian dan penghargaan guru, tujuan dan norma sekolah serta relasi teman sebaya, apakah ketiganya memiliki korelasi yang signifi-

Tabel 4

Hasil perhitungan deskriptif perundungan pada setiap SMA

\begin{tabular}{clcccc}
\hline No & Wilayah & Nama Sekolah & Jumlah & Mean (M) & SD \\
\hline 1 & Jakarta Utara & SMAN A & 131 & 23,76 & 12,18 \\
2 & Jakarta Barat & SMAN B & 164 & 26,68 & 13,73 \\
3 & Jakarta Pusat & SMAN C & 68 & 27,10 & 9,72 \\
4 & Jakarta Timur & SMAN D & 196 & 24,41 & 9,83 \\
5 & Jakarta Selatan & SMAN E & 164 & 23,02 & 8,86 \\
\hline
\end{tabular}


kan terhadap perundungan? Berikut hasil korelasi yang diperoleh:

Dimensi perhatian dan penghargaan guru memiliki korelasi negatif yang signifikan terhadap perundungan $(r=$ -0,206; $p<0,01)$. Hal ini berarti dimensi perhatian dan penghargaan guru memiliki kaitan dengan berkurangnya perilaku perundungan. Selain itu dimensi tujuan dan norma sekolah yang tampil dalam bentuk kejelasan aturan maupun sanksi dan apresiasi yang berlaku di sekolah, memiliki korelasi signifikan dengan arah negatif terhadap perundungan $(r=-0,172$; $p<0,01)$. Artinya semakin kuat dimensi tujuan dan norma sekolah dipersepsi oleh siswa, maka maka akan semakin rendah kemungkinan siswa menampilkan tingkah laku perundungan. Dimensi terakhir dari iklim sekolah, yaitu relasi teman sebaya juga memiliki korelasi yang signifikan dengan arah negatif terhadap perundungan $(r=-0,184 ; p<0,01)$. Dan akhirnya keseluruhan skala iklim sekolah ini memiliki korelasi yang signifikan dengan arah negatif terhadap perundungan $(r=-224$; $p<0,01)$. Artinya, semakin kuat iklim sekolah dipersepsi oleh siswa, maka akan semakin lemah kemungkinan siswa akan menampilkan perilaku perundungan di sekolah. Hasil uji korelasi di atas menyatakan bahwa baik ketiga dimensi iklim sekolah maupun iklim sekolah secara total, masing-masing memiliki korelasi yang negatif terhadap perundungan.

Seberapa besar peran iklim sekolah secara keseluruhan maupun dimensidimensi iklim sekolah berupa perhatian dan penghargaan guru, tujuan dan norma sekolah, serta relasi teman sebaya memberikan kontribusi pada munculnya perilaku perundungan pada siswa? Penjelasannya terdapat pada Tabel 5.

Pada tabel 5 terlihat bahwa dimensi perhatian dan penghargaan guru memberikan sumbangan pada perundungan sebesar 4,2 persen. Hal ini berarti sebanyak 4,2 persen perilaku perundungan dapat dicegah oleh perhatian dan penghargaan yang ditunjukkan guru di sekolah, dan selebihnya sebesar 95,8 persen dijelaskan oleh variabel lain di luar perhatian dan penghargaan guru. Sementara itu, variabel tujuan dan norma sekolah memberikan kontribusi sebesar 3,0 persen terhadap pencegahan perilaku perundungan pada siswa, dan sisanya sebesar 97 persen disumbang oleh variabel lain di luar variabel tujuan dan norma sekolah. Dimensi terakhir dari iklim sekolah yaitu relasi teman sebaya, memberikan kontribusi sebesar 3,4 persen terhadap pencegahan perilaku perundungan pada siswa, dan sisanya sebesar 94,6 persen disumbang oleh variabel lain di luar variabel relasi teman sebaya. Hasil uji regresi di atas juga memperlihatkan bahwa keseluruhan nilai total iklim sekolah

Tabel 5

Model Summary

\begin{tabular}{lcccc}
\hline \multicolumn{1}{c}{ Prediktor } & $\boldsymbol{R}$ & $\boldsymbol{R}$ Square & $\begin{array}{c}\text { Adjusted } \boldsymbol{R} \\
\text { Square }\end{array}$ & $\begin{array}{c}\text { Std. Error of the } \\
\text { Estimate }\end{array}$ \\
\hline IS1_Perhatian \& Perhargaan & $-0,206$ & 0,042 & 0,041 & 8,93470 \\
Guru & $-0,172$ & 0,030 & 0,028 & 8,99419 \\
IS2_Tujuan \& Tujuan Sekolah & $-0,184$ & 0,034 & 0,033 & 8,97427 \\
IS3_Relasi Teman Sebaya & $-0,224$ & 0,050 & 0,049 & 8,89720 \\
Iklim Sekolah & & &
\end{tabular}

Dependent Variable: Perundungan 
memiliki kontribusi sebesar 5 persen dalam mencegah terjadinya perundungan pada siswa, dan selebihnya sebesar 95 persen disumbang oleh variabel lain yang tidak diteliti dalam penelitian ini.

\section{Diskusi}

Partisipan dalam penelitian ini menilai iklim sekolah pada SMAN B Jakarta Barat lebih rendah dibandingkan dengan penilaian siswa di wilayah lain, dengan perbedaan yang signifikan. SMAN B Jakarta Barat terletak di komplek perdagangan dengan lalu lintas serta mobilitas yang padat. Sekolah ini telah lebih dulu ada sebelum sentra perdagangan berkembang seperti saat ini. Lokasi sekolah ini berada di tengah-tengah pemukiman penduduk, sehingga area sekolah dengan area tempat tinggal warga bercampur jadi satu. Selain itu, terdapat sekolah SD dan SMP yang berada satu kompleks. Dapat dikatakan lokasi sekolah saat ini tampak layak untuk menciptakan suasana belajar yang kondusif. Wajar bila kemudian siswa menilai iklim sekolahnya relatif rendah dibandingkan dengan penilaian siswa terhadap sekolahnya di wilayah ibu kota lainnya.

"Sekolah kami dapat dikategorikan sebagai sekolah cagar budaya. Sekolah ini sudah lama berdiri dan sempat mengalami sengketa lahan karena posisinya yang unik dan agak terjepit di antara bangunan-bangunan lain tempat usaha di daerah sini. Kabarnya ada rencana pemerintan untuk merelokasi sekolah ini, namun masih banyak pertimbangan lain, hingga saat ini belum dilakukan". Wawancara dengan Bapak $U$, Wakil Kepala Sekolah bidang Kesiswaan SMAN B, Jakarta Barat.

Selain itu, terdapat sekolah SD dan SMP yang berada satu kompleks. Dapat dibilang lokasi sekolah saat ini tampak kurang layak untuk menciptakan suasana belajar yang kondusif. Perundungan di sekolah ini secara umum dianggap siswa lebih tinggi secara signifikan dibandingkan dengan sekolah lainnya di wilayah provinsi DKI Jakarta. Pengawasan terbatas dari sekolah membuat kejadian perundungan dapat terjadi.

"Siswa mengikuti pembelajaran dengan sistem berpindah kelas, karenanya tidak setiap guru hafal di mana siswa kelas tertentu berada pada jam tertentu pula. Hal ini juga berdampak pada program-program penanganan perilaku siswa termasuk perundungan yang belum sepenuhnya dapat kami efektifkan". (Bapak $U$, Wakil Kepala Sekolah bidang Kesiswaan SMAN B)

Di antara lima sekolah yang menjadi sampel dalam penelitian ini, maka perundungan pada SMAN E, Jakarta Selatan, dipersepsi paling rendah oleh siswanya. Perbedaan ini cukup signifikan dibandingkan dengan sekolah-sekolah lainnya. SMAN E pada tahun-tahun sebelumnya terkenal dengan tradisi perundungan antara senior terhadap juniornya, terutama yang dilakukan oleh kakak alumni sekolah tersebut. Tindakan yang tegas dari Dinas Pendidikan dengan memanggil pimpinan sekolah terkait membuat sekolah ini segera bertindak menyelenggaran program anti-perundungan.

"Sekolah kami dengan cepat merespon tuntuntan orang tua dan teguran dari pihak dinas pendidikan, dengan melakukan pembenahan terhadap perundungan. Menyadari perlunya bantuan ahli, kami bekerja sama dengan Fakultas Psikologi dari salah satu universitas di kota Jakarta untuk melakukan program intervensi perundungan. Bentuknya adalah melakukan konseling pada siswa yang diduga menjadi pelaku maupun korban perundungan agar dapat mengelola trauma yang dialami. Selain itu, siswa juga diberi pelatihan untuk mampu berkomunikasi asertif saat menghadapi masalah di sekolah". Wawancara 
dengan Ibu D, guru BK SMAN E, Jakarta Selatan.

Temuan dari data deskriptif di atas menjelaskan bahwa faktor lingkungan sekolah seperti luas sekolah, lalu lintas yang terdapat di sekitar sekolah, ketersediaan sarana dan prasana belajar yang menunjang, merupakan hal penting pembentukan iklim sekolah. Hal ini sejalan dengan penelitian Jimmerson, Swearer dan Espelage (2009); maupun penelitian Konu, Alanen, Lintonen dan Rimpela (2002) yang menyatakan bawa kondisi sekolah merupakan faktor yang menentukan untuk mengukur sehat tidaknya sebuah sekolah, di samping faktor-faktor lainnya seperti kualitas hubungan sosial, pemenuhan hak-hak siswa dan faktor lingkungan kesehatan. Pada konsep school well being, Konu dkk (2002) menyatakan faktor kondisi sekolah meliputi luas sekolah, lingkungan di sekitar sekolah, manajemen sekolah maupun layanan yang diberikan sekolah bagi siswa. School well being yang positif akan menjadi faktor yang efektif dalam pencegahan perundungan (Konu dkk, 2002; Klein, Cornell, Konold, 2012; Toner, 2010, Summers, 2008).

Rendahnya tingkah perundungan pada SMAN E, Jakarta Selatan sebagaimana yang dipersepsikan oleh para siswanya, tidak terlepas dari sejumlah program intervensi yang telah dijalankan sekolah ini selama kurun waktu satu tahun terakhir. Pelibatan para ahli, penyediaan layanan konsultasi siswa, pelatihan untuk siswa dan guru, bahkan pelibatan orang tua dalam bentuk program parenting, mampu memunculkan kesadaran untuk mencegah perundungan. Hal tersebut mampu membuat sekolah tampil ramah. Sekolah yang ramah ternyata memiliki pengaruh terhadap rendahnya tingkat perundungan di sekolah (Halimah,
Khumas, dan Zainuddin, 2015). Lebih jauh, Espelage, Polanin dan Low (2014) menyatakan, dalam pencegahan perundungan di sekolah, seluruh pemangku kepentingan sudah selayaknya dilibatkan. Guru, siswa, orang tua, merupakan pihakpihak penting yang harus disentuh. Selain itu, psikolog sekolah/guru bimbingan konseling, perlu berperan aktif dalam program penanganan perundungan, demikian juga staf akademik lainnya (Sullivan, 2000). Menurut Espelage dkk (2014) dalam penelitiannya, keterlibatan kuat dari guru maupun staf akademik di sekolah dalam intervensi program-program perundungan dilaporkan menurunkan tingkat terjadinya perundungan secara signifikan. Bahwa intervensi yang dilakukan di sekolah akan memberikan dampak positif bagi siswa, juga disimpulkan oleh Ryan (2009) dalam penelitiannya. Ia melakukan pengukuran tingkat perundungan pada sekolah yang telah diberlakukan program anti-perundungan. Hasil pengukuran menunjukkan bahwa program anti perundungan yang dilakukan terbukti menjadi cara yang efektif dalam pencegahan perundungan.

Pengujian dimensi-dimensi dalam komponen iklim sekolah dalam penelitian ini menunjukkan hasil yang signifikan pada ketiga dimensi secara terpisah, maupun pada iklim sekolah secara umum. Pentingnya perhatian dan penghargaan guru, memberikan sumbangan yang signifikan terhadap pencegahan perundungan. Hal ini sejalan dengan penelitian Baker yang dirujuk oleh Douglass (2009). Siswa yang memiliki persepsi positif terhadap sekolah, umumnya menilai guru mereka bersahabat, ramah dan mampu menjalin komunikasi efektif (Collie, Shapka, \& Perry, 2012). Guru juga tidak segan memberikan apresiasi yang positif terhadap siswa seperti pujian dan 
penghargaan terhadap prestasi siswa, dan tidak melulu berfokus pada kesalahan siswa (Douglass, 2009).

Selain perhatian dan dukungan guru, penelitian ini juga menyajikan hasil bahwa dimensi tujuan dan norma sekolah juga memiliki pengaruh yang signifikan dalam pencegahan perundungan. Penerapan aturan yang jelas dengan kedisiplinan sebagai bagian dari tata tertib yang membingkai perilaku siswa, terbukti memiliki dampak yang efektif. Dapat dipahami bila sanksi dan aturan tegas yang diserukan oleh Dinas Pendidikan DKI maupun pemda setempat, ternyata diperlukan oleh sekolah sebagai landasan dalam membuat aturan dan penerapan sanksi. Namun demikian, penerapan aturan dan sanksi tegas tersebut sebaiknya tidak hanya dilakukan saat perundungan telah terjadi, namun disosilisasikan dalam bentuk nilai dan norma yang dijadikan patokan oleh sekolah. Hasil ini sejalan dengan penelitian Cornell, Shukla, dan Konold (2015) yang menyebutkan bahwa praktek kedisiplinan di sekolah yang ditandai oleh komponen adanya struktur yang jelas dan dukungan yang suportif terbukti berkaitan dengan rendahnya perilaku perundungan.

Dimensi relasi teman sebaya dalam penelitian ini, sebagaimana dimensi pada iklim sekolah lainnya, menunjukkan pengaruh yang bermakna terhadap pencegahan perundungan. Relasi antar teman sebaya diyakin merupakan aspek penting dalam menumbuhkan perasaan nyaman dan aman pada siswa. Menimbang bahwa responden dalam penelitian ini terkategori pada usia remaja, dapat dipahami bila peran teman sebaya merupakan aspek penting bagi remaja. Hasil ini sejalan dengan penelitian Douglass (2009) maupun Jesse, Ellen, Julie, dan Matthew (2013), yang menyatakan bahwa relasi antar siswa merupakan faktor kritis utama bagi remaja, apalagi mengingat siswa lebih banyak menghabiskan waktunya dengan teman sebayanya dalam kesehariannya. Proyek penelitian Fox dan Bolton yang diacu oleh Douglass (2009) menginformasikan bahwa dalam relasi teman sebaya, aspek keterampilan sosial antar teman sebaya menjadi variabel yang penting. Keterampilan sosial yang memadai, akan membuat remaja mampu beradaptasi secara tepat sehingga tidak terjerumus pada tindakan perundungan.

Dari ketiga dimensi iklim sekolah, maka dimensi perhatian dan penghargaan guru ternyata memiliki pengaruh yang paling besar terhadap pencegahan perundungan. Temuan ini menarik. Aspek penegakkan norma dan aturan sekolah dalam pencegahan perundungan, berupa sanksi dan hukuman bagi pelanggar yang gencar disosialisasikan oleh dinas pendidikan saat ini ternyata bukan aspek yang paling penting bagi siswa. Aspek perhatian guru bagi siswa di DKI Jakarta, justru merupakan aspek yang memiliki peran terbesar. Hal ini menggarisbawahi pentingnya keterlibatan guru secara optimal dalam penanaman nilai-nilai positif di sekolah. Guru pada masa kini, tidak cukup hanya memberikan perhatian pada pencapaian prestasi akademik siswa. Guru perlu memberikan perhatian pada perilaku yang ditunjukkan siswa sehari-hari, termasuk membangun komunikasi timbal balik serta memperhatikan perkembangan sosial siswa. Dengan demikian diharapkan nilainilai positif dapat terinternalisasi pada diri siswa, serta tampil dalam bentuk tingkah laku yang sesuai norma sosial.

\section{Kesimpulan}

Ada beberapa kesimpulan yang dapat dilihat dari penelitian ini. Pertama, iklim sekolah memiliki pengaruh terhadap 
pencegahan perundungan. Iklim sekolah yang positif menandakan sekolah tersebut mampu membangun suasana psikologis yang sehat bagi setiap anggota sekolah, baik pimpinan sekolah, guru, staf akademik lainnya, maupun siswa. Kedua, komponen-komponen penting dalam iklim sekolah dalam pencegahan perundungan adalah terdapatnya perhatian dan dukungan guru, kejelasan aturan dan norma sekolah, serta relasi harmonis antar teman sebaya. Ketiga, sebagai pendidik, guru memainkan peran paling sentral. Perhatian dan penghargaan yang diberikan guru dalam penelitian ini terbukti memberikan kontribusi paling kuat terhadap pencegahan perundungan dibandingkan dimensi lainnya pada iklim sekolah. Implikasi yang dapat diperoleh dari kesimpulan ini adalah, pentingnya guru memberikan perhatian dan penghargaan kepada siswa untuk aspek-aspek perkembangan yang dicapai oleh siswa. Guru diharapkan tidak hanya memberikan dukungan dan penghargaan pada siswa semata pada aspek pengembangan kognitif; namun juga pada pembentukan sikap yang positif terhadap kompetensi sosial, seperti kemampuan bekerja sama, sikap menghormati orang lain serta keterampilan untuk saling menghargai.

\section{Saran}

Saran-saran terkait hasil penelitian ini patut dipertimbangan untuk penelitian berikutnya. Pertama, sebagai remaja akhir, siswa SMA membutuhkan bimbingan dan dukungan guru dalam pencegahan perundungan. Pelatihan yang bersifat aplikatif mengenai pengembangan karakter positif bagi guru maupun siswa perlu difokuskan dan diberikan secara berkala. Kedua, responden penelitian ini adalah siswa pada jenjang SMA, dan berasal dari sekolah negeri di Jakarta dengan karakteristik tertentu. Penelitian selanjutnya dapat dilakukan pada siswa di level yang lebih rendah, seperti SMP dan SD untuk mengeklsplorasi peran iklim sekolah terhadap perundungan. Ketiga, sekolah-sekolah dengan ciri khusus, seperti sekolah kejuruan, sekolah keahlian khusus maupun sekolah bernuansa agama yang dikelola oleh Kementrian Agama, juga menarik untuk diteliti. Sekolah-sekolah tersebut memiliki tradisi, budaya maupun nilainilai yang bersifat khusus, yang dapat menjadi informasi berharga bila dikaitkan dengan perundungan.

\section{Kepustakaan}

Abidin, Z., \& Milla, M. N. (Ed.). (2013). Isuisu mutakhir dalam penelitian psikologi sosial di Indonesia. Pekanbaru : AlMujtahadah Press

Adair, V. (1999). No bullies at this school: creating safe schools. ChildreNZ Issues, Journal of Childres's Issues Center, 3 (1), 32-37.

Arora, T. (1994). Measuring bullying with the 'Life in School' checklist. Pastoral Care, 12, 11-16.

Collie, R. J., Shapka, J. D., \& Perry, N. E. (2012). School climate and socialemotional learning: predicting teacher stress, job satisfaction, and teaching efficacy. Journal of Educational Psychology. 4. 1189-1204.

Cornell, D., Shukla, K., \& Konold, T. (2015). Peer victimization and authoritative school climate: A multilevel approach. Journal of Educational Psychology, 107(4), 1186-1201. Retrieved from http://search.proquest.com/docview/16 76345151 ? accountid $=17242$

Crapanzano, A. M. (2010). Understanding Bullying Participant Roles: Stability across School Years and Personality and 
Behavioral Correlates. A Dissertation Presented to the Graduate Faculty of the University of New Orleans. Ann Arbor: ProQuest, LLC.

Douglass, K. R. (2009). A Study of The Relationship Between Group Perception of School Climate and Incidences of Bullying at The Junior High/Middle School Level. A Dissertation Presented to University of Massachusetts. Ann Arbor: ProQuest, LLC.

Espelage, D. L., Polanin, J. R., \& Low, S. K. (2014). Teacher and staff perceptions of school environment as predictors of student aggression, victimization, and willingness to intervene in bullying situations. School Psychology Quarterly, 29(3), 287-305. Retrieved from http://search.proquest.com/docview/15 51094658 ? accountid $=17242$

Gottfredson, G. D., Gottfredson, D. C., Payne, A. A., \& Gottfredson, N. C. (2005). School climate predictors of school disorder: Results from a national study of delinquency prevention in schools. Journal of Research in Crime and Delinquency, 42, 412-444.

Halimah, A., Khumas, A., \& Zainuddin, K. (2015). Persepsi pada bystander terhadap intensitas bullying pada siswa SMP. Jurnal Psikologi, 42(2), 129140. doi: http://dx.doi.org/10.22146/ jpsi.7168

Hoffman, B. (2010). Cooperative learning, character education, conflict resolution among eighth graders, their teacher intervention with bullying and their experiences with cyber, physical, and relational bullying. Department of Educational Administration, Leadership and Technology Dowling College. Ann Arbor: ProQuest, LLC.

Jesse, S., Ellen, V., Julie, L., \& Matthew, S. (2013). Bullying among adolescent football players: role of masculinity and moral atmosphere. Ann Arbor: ProQuest, LLC.

Jimerson, S. E., Swearer, S. M., \& Espelage, D. L. (2009). Handbook of bullying in school: An international perspective. USA: Routledge.

Kenneth, M., Barbara, G., Scott, R., \& Duane, I. (2013). How effective are school bullying intervention programs? A metaanalysis of intervention research. Ann Arbor: ProQuest, LLC.

Klein, J., Cornell, D., \& Konold, T. (2012). Relationships between bullying, school climate, and student risk behaviors. School Psychology Quarterly, 27(3), 154-169.

Kogan, G. (2011). A Systematic Review of The Literature on The Effects of School Bullying from The Framework of Jurgen Habermas's Theory of Communicative Action. A Dissertation Presented to the Graduate Faculty of Social Welfare, The City University of New York. Ann Arbor: ProQuest, LLC.

Konu, A., Alanen, E., Lintonen, T., \& Rimpela, M. (2002). Factor structure of the school well-being model. Health Education Research, 17(6), 732-742.

McCaskill, V. M. (2013). Bullying prevalence in mississippi: A comparison of urban and rural schools (Order No. 3565338). Available from ProQuest Dissertations \& Theses Global. (1413312627). Retrieved from http://search. proquest.com/docview/1413312627?ac countid $=17242$

news.okezone.com/read/2016/05/09/338/13835

74/ahok-ancam-pecat-guru-yangmembiarkan-bullying-di-sekolah

Orpinas, P, \& Horne, A. M. (2006). Bullying prevention: Creating a positive school climate and developing social competence, 
Washington, DC: American Psychological Association.

Paramo, J. A. (2012). School Bullying: A Systematic review of The Literature. A Thesis Presented to the School of Social Work California State University, Long Beach. Ann Arbor: ProQuest, LLC.

Pozzoli, T., \& Gini. G. (2010). Active defending and passive bystanding behavior in bullying: The role of personal characteristics and perceived peer pressure. J Abnorm Child Psychol, 38, 815-827.

Rahmawati, S.W. (2017). Bullying siswa di sekolah menengah atas: Peran holistic parenting dan iklim sekolah terhadap bullying melalui variabel mediasi trait kepribadian lima besar. Disertasi. Bandung: Universitas Padjadjaran.

Ryan, W. (2009). School Climate and Bullying. A Thesis Presented to the Faculty of Graduate and Postdoctoral Studies Canada's University. Ottawa: Published Heritage Branch, Inc.

Socoski, P. M. (2006). Bullying prevention: Creating a positive school climate and developing social competence. Choice, 43(8), 1455. Retrieved from http:// search.proquest.com/docview/2257442 69? accountid $=17242$

Summers, K. H. (2008). The relationship among bullying participant roles, social support, and school climate (Order No. 3335063). Available from ProQuest Dissertations \& Theses Global. (304540706). Retrieved from http://search.proquest.com/docview/30 4540706 accountid $=17242$

Sutherland, A. E. (2010). The Roles of School Climate and Peers in Bullying. A Thesis Presented to the Department of Psychology Queen's University. Ottawa: Published Heritage Branch, Inc.

Sullivan, K. (2000). The Anti-bullying handbook. UK: Oxford University Press.

Toner, B. K. (2010). The Implementation of The Bully Prevention Program: Bully Proofing your School and its Effect on Bullying and School Climate on Sixth Grade Suburban Students. A Dissertation Presented to the Faculty of the School of Human Service Professions Widener University. Ann Arbor: ProQuest, LLC.

Ttofi, M. M., Farrington. D. P., Losel. F., \& Loeber. R. (2011). Do the victims of school bullies tend to become depressed later in life? A systematic review and meta-analysis of longitudinal studies. Journal of Aggression, Conflict and Peace Research, 2, 63-73.

Waasdorp, T. E., Bradshaw, C. P., \& Duong, J. (2011). The link between parents' perceptions of the school and their responses to school bullying: Variation by child characteristics and the forms of victimization. Journal of Educational Psychology, 103(2), 324-335. Retrieved from http://search.proquest. com/docview/857824090?accountid=17 242

http://sejiwa.org/profile/ 